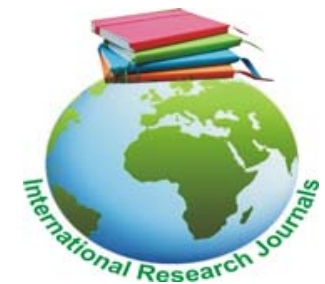

African Journal of Food Science and Technology ((ISSN: 2141-5455) Vol. 6(1) pp. 12-17, January, 2015

DOI: http:/dx.doi.org/10.14303/ajfst.2014.109

Available online @http://www.interesjournals.org/AJFST

Copyright @2015 International Research Journals

Full Length Research Paper

\title{
Effect of Grewia venusta('Ururu') mucilage on the physicochemical and sensory properties of fried cake ('akara') prepared from bambara groundnut seed flour
}

\author{
Alobo, Arubi P* and Arueya, Gibson L. \\ Department of Food Technology, University of Ibadan, Ibadan, Nigeria. \\ * Corresponding Author. E-mail: apalobo@yahoo.com Tel: 234- 8063370228
}

Abstract

\begin{abstract}
Grewia venusta ('Ururu') mucilage was applied in the preparation of fried bambara groundnut cake ('Akara') to study its physicochemical and sensory properties. Batches of akara containing $\mathbf{0 - 2} \%$ mucilage were prepared by deep-fat-frying. The physical properties, proximate composition and sensory attributes of the akara were studied. The weight, volume and dimensions of the akara balls increased due to mucilage addition. The air spaces in the akara crumbs increased in number (56-295) with increasing level of mucilage. The akara crumbs became progressively spongy and their texture and flavour received higher scores than the control. The akara with $0 \%$ and $0.5 \%$ mucilage had the most attractive colour as shown by the panelists' scores (4.8 and 4.4, respectively). The scores for colour of akara with $1.0 \%$ and $1.5 \%$ mucilage were not different significantly. The moisture, fibre, fat and ash contents of theakara increased while protein and carbohydrate decreased with increasing mucilage addition. The results suggested that apart from protein and colour, the quality of bambara groundnut akara improved upon addition of mucilage. The preparation of akara from bambara groundnuts with added Grewia venusta mucilage would help to diversify the utilization of the nuts as well as promote the use of a lesser known mucilage in food.
\end{abstract}

Keywords: Grewiavenusta, mucilage, 'akara', physicochemical, sensory properties.

\section{INTRODUCTION}

'Akara' is a traditional African food prepared by deep-fatfrying cow pea paste flavoured with onions, pepper and salt (Lete, 2013). The food is popular among both rural and city dwellers in Nigeria and it is either eaten along with 'akamu' (a custard-like gruel prepared from maize, sorghum or millet) or whole meal millet gruel. Traditionally, cow pea paste is prepared by soaking, wetdehulling and wet-milling of cow pea seeds. Whipping of thepaste is an important aspect of akara preparation as it helps to incorporate air to facilitate foam formation (Ngoddyet al., 1986). Foam formation gives rise to increased number of air spaces in the paste, which results in porous and spongy akara crumb that is cherished by consumers.Apart from cow peas, bambara groundnuts (BGN) have been used as an ingredient in the preparation of akara among rural populations in
Nigeria, particularly in the north central states where the nuts are cultivated.

Bambara groundnut is a leguminous crop grown in tropical and sub-tropical countries of the world (Chinedu and Nwinyi, 2012). It is grown extensively in Nigeria and other parts of West Africa (Okpuzoet al, 2010). Although the nuts are produced in large quantities $(100,000$ metric tonnes $\{$ MT in Nigeria; 30,000 MT in Niger and 20,000 MT in Ghana) (Asiedu, 1989) it is not popular and its use is limited mainly to the preparation of steamed cake ('Okpa'). BGN has potential use in addressing the protein-energy malnutrition problem in developing countries because it is a proteinous food with a high amount of carbohydrates (Mazahibet al., 2013; Chinedu, and Nyinyi, 2012). The growing awareness of malnutrition to be a major health problem in developing countries has resulted in various efforts that are made to introduce new 
food sources and development of methods for increased utilization of less popular foodstuffs. For example, Alobo (1999) and Olapade and Adetuyi (2007) have used procedures such as hot water soaking, steaming, autoclaving and roasting to improve the removal of BGN seed coats prior to the preparation of akara and 'moinmoin' (steamed paste). BGN is adapted to both arid and wet climates and it tolerates poor soil in which most other legumes like cow pea and soya beans will not survive (Chinedu, and Nyinyi, 2012). The nuts are produced underground and their pods are hard and wrinkled when dry. BGN seeds are hard and usually round, with colour ranging from cream to white and may possess a combination of various colours. Legume seed coats are usually removed prior to further processing in order to improve the appearance, texture, cooking quality and palatability of products derived from the seeds (Akinjeyaju and Enude, 2002). Unlike cow peas, which are wet-dehulled and milled to prepare akara, BGN seeds cannot be efficiently dehulled after soaking. Thus the traditional approach in akara preparation from the seeds involves dry milling and sieving of the seeds into flour. The flour is mixed with relevant ingredients and then hydrated to form paste. However, paste prepared from BGN flour results in noticeable problems in akara, which include poor swelling and akara balls that are flat with non-spongy crumb. In an effort to overcome these short comings, liquid Grewia venusta (ururu) mucilage is usually applied in the preparation of paste from BGN flour to produce akara. In spite of this use, the role played by the mucilage in the akara has not been documented in the literature.

Mucilages are thick and slimy substances produced by many plants and microorganisms. They are materials which possess the ability to thicken or gel aqueous systems (Dawidowsky, 2009). They are referred to as hydrocolloids and they possess high molecular weight polymeric compounds. The compounds are mostly polysaccharides that are characterized by the ability to produce highly viscous solutions at low concentrations (Olusolaet al., 2014). Mucilage is edible but tastes rather bland and mucilaginous foods are commonly used to impart a desired slimy consistency to local soups and stew (Anonymous, 2010).

The aim of this work was to undertake a prior extraction and drying of mucilage from Grewia venusta (ururu) and then apply the mucilage in the preparation of akara from bambara groundnut seed flour. The study would assess the physicochemical and sensory properties of the akara after using the mucilage.

\section{MATERIALS AND METHODS}

\section{MATERIALS}

Grewia venusta (Ururu) stems were obtained from trees in Ajaokuta, Kogi State, Nigeria. Other materials,including bambara groundnut seeds, salt, vegetable oil fresh red pepper and onions were purchased at the local market in Idah, Kogi State, Nigeria.

\section{Preparation of mucilage}

Grewia venusta mucilage was extracted following the procedure of Iwe and Attah (1993) with modifications. The G.venusta stem bark was cleaned by scrapping off the outer powdery covering. The cleaned stem bark was then peeled off and cut into pieces of about $25 \mathrm{~cm}$ long and weighed. The pieces were reduced to thin strips, which were then pounded using pestle and mortar. Clean water $(2,500 \mathrm{ml})$ was added to the pounded mass, which was squeezed to extract the mucilage. The extract was then filtered using a double-folded muslin cloth. The filtered extract was dried at $60 \pm 3^{\circ} \mathrm{C}$ in an air oven (Gallenkamp BS 200, England), milled and sieved using a laboratory sieve of 120 mesh.

\section{Preparation of flour from bambara groundnut seeds}

Bambara groundnut seeds were mechanically crackedusing attrition mill (No 1A Premier Mill, A44 BA, UK)and winnowed to separate the seed coats. The cotyledons were milled and sieved into flour using a sieve of 80 mesh.

\section{Preparation of 'akara'}

Akara was prepared using the recipe shown in Table 1. The onion and pepper were ground using Moulinex electric blender (Type 241.2.00, France).Batches of akara containing $0 \%, 0.5 \%, 1.0 \%, 1.5 \%$ and $2.0 \%$ mucilage were prepared as follows.A smooth paste was prepared by addition of water to the flour. The ground pepper, mucilage powder, onion and salt were added to the paste. The paste was whipped for oneminute using a wooden ladle.Portions of the whipped paste were dropped into hot vegetable oil in a frying pan placed over gas heat and deep-fried for 7 minutes to yield akara. The fried akara balls were placed on a perforated stainless steel tray and left for 2 minutes to drain oil.

\section{Physical measurements of akara balls}

The weight of three akara balls was measured using a top loading weighing balanceand meanvalues were recorded. The length or diameter was measured at three different points using vernier caliper and mean values were calculated. Volume was computed using the values for diameter. The air spaces within the akara balls were counted after the balls have been sliced into halves. 
Table 1.Recipe for the preparation of akara from bambara groundnut seeds.

\begin{tabular}{lc}
\hline Ingredient & Quantity \\
Bambara groundnut flour $(\mathrm{g})$ & 200 \\
\hline Fresh red pepper $(\mathrm{g})$ & 3 \\
Fresh onion $(\mathrm{g})$ & 30 \\
Salt $(\mathrm{g})$ & 1 \\
Water $(\mathrm{ml})$ & 120 \\
\hline
\end{tabular}

\section{Proximate composition}

Moisture content was determined by the AOAC (2005) method. Two gram of sample was weighed into previously washed, dried and weighed crucible. The crucible with the sample was transferred into an air oven (Memmert, Biotechnic, India) at $105{ }^{\circ} \mathrm{C}$ and the sample was dried to a constant weight. Moisture content was calculated and expressed as percent weight loss.

The ash content was determined using AOAC (2005) method. Two gram of sample was weighed into a previously washed, dried and weighed crucible. The sample was charred and then put into a muffle furnace to ash at a temperature of $500{ }^{\circ} \mathrm{C}$. It was then cooled in a desiccator, weighed and the ash content was calculated as a percentage of the initial weight of sample.

Protein content was determined using the kjeldahl method according to AOAC (2005). Two gram of sample was digestedusing $25 \mathrm{ml}$ concentrated tetraoxosulphate $\mathrm{VI}$ acid and $8 \mathrm{~g}$ of mixed sodium tetraoxosulphate $\mathrm{VI}$ $\left(\mathrm{Na}_{2} \mathrm{SO}_{4}\right)$ copper tetraoxosulphate $\mathrm{VI}\left(\mathrm{CuSO}_{4}\right)$ and selenium dioxide catalyst. Crude protein\% was calculated as crude nitrogen $\times 6.25$.

Fat content was determined on $2 \mathrm{~g}$ of sample using soxhlet fat extraction method as described by AOAC (2005). Petroleum ether was used as solvent. The sample was allowed to reflux for 6 hours. The extracted fat was calculated as a percentage of the initial weight of sample.

The method described by AOAC (2005) was used for fibre determination. The sample $(2 \mathrm{~g})$ was weighed into a $600 \mathrm{ml}$ flask and $200 \mathrm{ml}$ of hot $1.25 \% \mathrm{H}_{2} \mathrm{SO}_{4}$ was added and was boiled under reflux for 10 minutes. It was then filtered using a weighed ashless filter paper. The residue was transferred from the paper back to the flask with the aid of hot $1.25 \% N_{a} \mathrm{OH}$ and the volume adjusted to $200 \mathrm{ml}$. The digest was returned to the digestion flask and boiled under reflux for 30 minutes. The digested sample was filtered and the residue was dried at $100{ }^{\circ} \mathrm{C}$ for 2 hours. It was cooled in a desiccator and weighed (weight A). The dried ample was put in a furnace at $600{ }^{\circ} \mathrm{C}$ for 6 hours, cooled in a desiccator and weighed (weight B). The loss in weight upon incineration represented the weight of crude fibred in the sample.

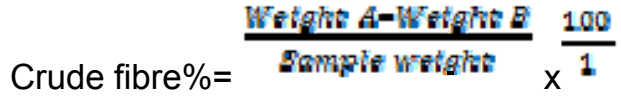

The Carbohydrate content (\%) was determined by the difference method (AOAC, 2005), where carbohydrate = $100-\%$ (fat + protein + ash + moisture + crude fibre) .

\section{Sensory evaluation}

The akara balls were evaluated for colour, taste, flavour, texture and overall acceptability by a 10 -member panel comprising male and female subjects who were familiar with the food. The assessment was conducted under fluorescent illumination inside isolated booths within an air-conditioned sensory evaluation laboratory. A modified 5 -piont hedonic scale (where $5=$ like very much and $1=$ dislike very much) (Ihekoronye and Ngoddy, 1985) was used for the assessment. The akara samples were coded and served on white saucers. Fresh water was provided to rinse the mouth between evaluations.

\section{Statistical analysis}

The analytical and sensory data generated were subjected to analysis of variance and differences were discriminated using least significant difference (LSD) test at $5 \%$ probability level according to Ihekoronye and Ngoddy (1985).

\section{RESULTS AND DISCUSSION}

\section{Physical properties of akara}

The G. venusta stem bark yielded mucilage that was reddish brown to brick red in colour. Table 2 presents the physical properties of akara mixed with the G. venusta (ururu) mucilage. The weight of akara balls with $0.5 \%$, $1.0 \%$ and $1.5 \%$ mucilage were not significantly different $(p \geq 0.05)$ from each other but were significantly different from the control (0\% mucilage) and akara with $2.0 \%$ mucilage. There were minimal but non-significant 
Table 2. Physical properties of Bambara groundnut akara as affected byGrewia venusta mucilage

\begin{tabular}{|c|c|}
\hline \multicolumn{2}{|r|}{ Level of mucilage $(\%, w / w)$} \\
\hline $0 \quad 0.5$ & $\begin{array}{lll}1.0 & 1.5 & 2.0\end{array}$ \\
\hline Weight (g) & $24.02^{\mathrm{a}} 24.08^{\mathrm{ab}} 24.16^{\mathrm{b}} 24.23^{\mathrm{b}} 24.50^{\mathrm{c}}$ \\
\hline Diameter $(\mathrm{cm})$ & $4.33^{\mathrm{a}} 4.38^{\mathrm{a}} 4.40^{\mathrm{a}} 4.43^{\mathrm{a}} 4.48^{\mathrm{a}}$ \\
\hline Height $(\mathrm{cm})$ & $2.65^{\mathrm{a}} 3.90^{\mathrm{b}} 4.45^{\mathrm{bc}} 4.60^{\mathrm{c}} 4.65^{\mathrm{c}}$ \\
\hline Volume $\left(\mathrm{cm}^{3}\right)$ & $42.67^{\mathrm{a}} 43.86^{\mathrm{b}} 44.47^{\mathrm{D}} 45.70^{\mathrm{c}} 46.94^{\mathrm{a}}$ \\
\hline *Air space & $56.00^{\mathrm{a}} 128.00^{\mathrm{b}} 154.00^{\mathrm{b}} 257.00^{\mathrm{c}} 295.00^{\mathrm{c}}$ \\
\hline
\end{tabular}

Values are means of triplicate determinations. Means in a given row with different superscripts differ significantly ( $p \leq 0.05)$.

*Mean number of air spaces for two different cut surfaces.

Table 3. Proximate composition (\%) of bambara groundnut akara containing Grewiavenusta mucilage

\begin{tabular}{lll}
\hline Parameter & \multicolumn{1}{c}{ Level of mucilage $(\%, w / w)$} \\
\hline 0 & 0.5 & 1.0 \\
Moisture & $30.40^{\mathrm{a}} 30.03^{\mathrm{b}} 30.44^{\mathrm{c}} 30.60^{\mathrm{c}} 31.23^{\mathrm{c}}$ & 2.0 \\
Fat & $13.80^{\mathrm{a}} 13.9^{\mathrm{b}} 14.23^{\mathrm{b}} 14.29^{\mathrm{b}} 14.34^{\mathrm{b}}$ & \\
Protein & $14.01^{\mathrm{a}} 13.57^{\mathrm{b}} 13.55^{\mathrm{b}} 13.20^{\mathrm{b}} 13.13^{\mathrm{c}}$ & \\
Fibre & $3.70^{\mathrm{a}} 4.00^{\mathrm{ab}} 4.39^{\mathrm{bc}} 4.75^{\mathrm{cd}} 5.05^{\mathrm{d}}$ & \\
Ash & $2.53^{\mathrm{a}} 2.54^{\mathrm{a}} 2.57^{\mathrm{ab}} 2.60^{\mathrm{ab}} 2.62^{\mathrm{b}}$ & \\
Carbohydrate & $35.56^{\mathrm{a}} 35.95^{\mathrm{a}} 34.82^{\mathrm{bc}} 34.56^{\mathrm{c}} 33.63^{\mathrm{d}}$ & \\
\hline
\end{tabular}

Values are means of duplicate determinations. Means in a given row with different letters differ significantly $(p \leq 0.05)$.

Table 4. Mean sensory scores of bambara groundnut akara containing Grewiavenusta mucilage

\begin{tabular}{lll}
\hline Attribute & \multicolumn{3}{c}{ Level of mucilage $(\% \mathrm{w} / \mathrm{w})$} \\
\hline 0 & 1.0 & 2.0 \\
Appearance & 2.5 & \multicolumn{2}{c}{1.5} & \\
Colour & $4.0^{\mathrm{a}} 3.0^{\mathrm{b}} 4.0^{\mathrm{c}} 4.0^{\mathrm{c}} 5.0^{\mathrm{d}} 3.7^{\mathrm{b}} 3.8^{\mathrm{b}} 3.1^{\mathrm{c}}$ & \\
Taste & $4.5^{\mathrm{ab}} 3.1^{\mathrm{d}} 3.6^{\mathrm{c}}$ & $4.1^{\mathrm{b}} 4.6^{\mathrm{a}}$ \\
Texture & $4.2^{\mathrm{a}} 4.2^{\mathrm{a}} 4.5^{\mathrm{ab}}$ & $4.6^{\mathrm{b}} 4.8^{\mathrm{b}}$ \\
Flavour & $4.1^{\mathrm{a}} 4.3^{\mathrm{a}} 4.2^{\mathrm{bc}} 4.4^{\mathrm{abc}}$ & $4.7^{\mathrm{a}}$ \\
Overall & $3.3^{\mathrm{a}} 3.6^{\mathrm{ab}} 3.8^{\mathrm{ab}} 4.0^{\mathrm{b}}$ & $4.8^{\mathrm{c}}$ \\
acceptability & & \\
\hline
\end{tabular}

Means followed by different letters in a row are significantly different $(p \leqslant 0.05)$. Appearance was rated on a descriptive scale $(5=$ smooth and round in shape, $1=$ rough and pebbling crust). Other attributes were rated on a 5 point hedonic scale ( $5=$ like very much, $1=$ dislike very much).

$(p \geq 0.05)$ increases in the diameter of the akara balls upon inclusion of mucilage at any given concentration. On the other hand, the heights of the balls increased significantly $(p \leq 0.05)$ with increasing mucilage addition, except for those containing 1-2\% mucilage, which were not significant. The increase resulted in heights that were similar to or higher than the diameter of the control akara. This gave rise to the akara balls becoming more rounded and uniform in shape (Plate 1 and 2). The mucilage improved the smoothness of the crust and the regularity of the shape of the akara balls prepared from bambara groundnut flour. The higher the quantity of mucilage used, the smoother and more regular the akara balls became. The samples with $1.5 \%$ and $2.0 \%$ mucilage were more regular in shape and smoother in the outer crust, appearing more interesting and attractive unlike the sample without mucilage which was rough and irregular in shape. Indeed, the appearance of akara balls containing $2 \%$ mucilage was described as slightly smooth and round in shape and it earned significantly higher score than the control and those containing lower percentage of mucilage (Table 4).

Increase in diameter and height of theakara balls resulted in an increase in their volumes. The number of air spaces (cells) within the akara crumbs increased with increasing mucilage concentration. The mucilage contributed to the increasing inclusion of air during whipping of the akara batter, which resulted in a spongy characteristic of the crumbs. The change in shape and increase in size of the akara balls were due to swelling and aeration brought about by the mucilage.

\section{Proximate composition of akara}

The proximate composition of akara prepared from bambara groundnut flour with added $G$. venusta (ururu) 
16 Afr. J. Food Sci. Technol.

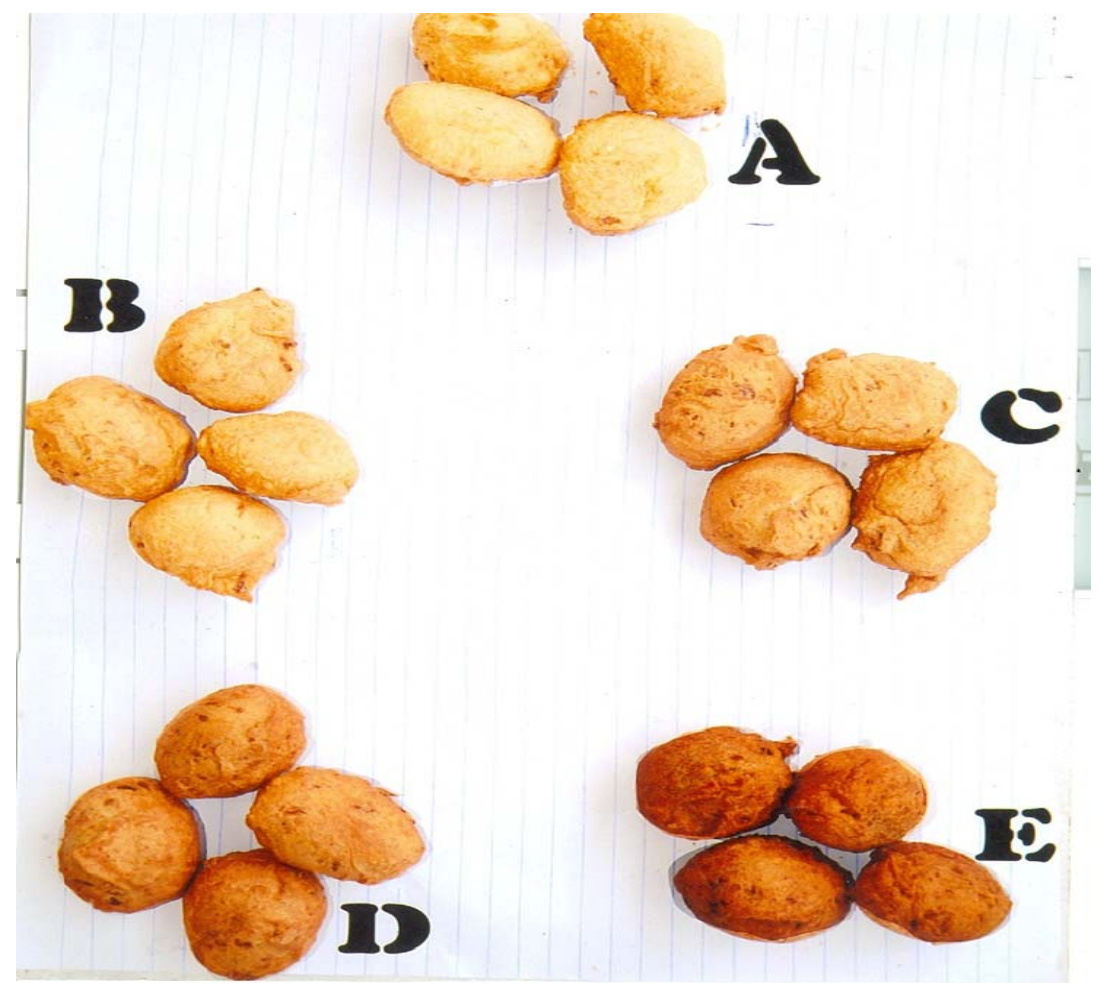

Figure 1. Akara balls from bambara groundnut flour containing Grewiavenusta mucilage $(\%, w / w) . A=0, B=0.5, C=1.0, D=1.5, E=2.0$.

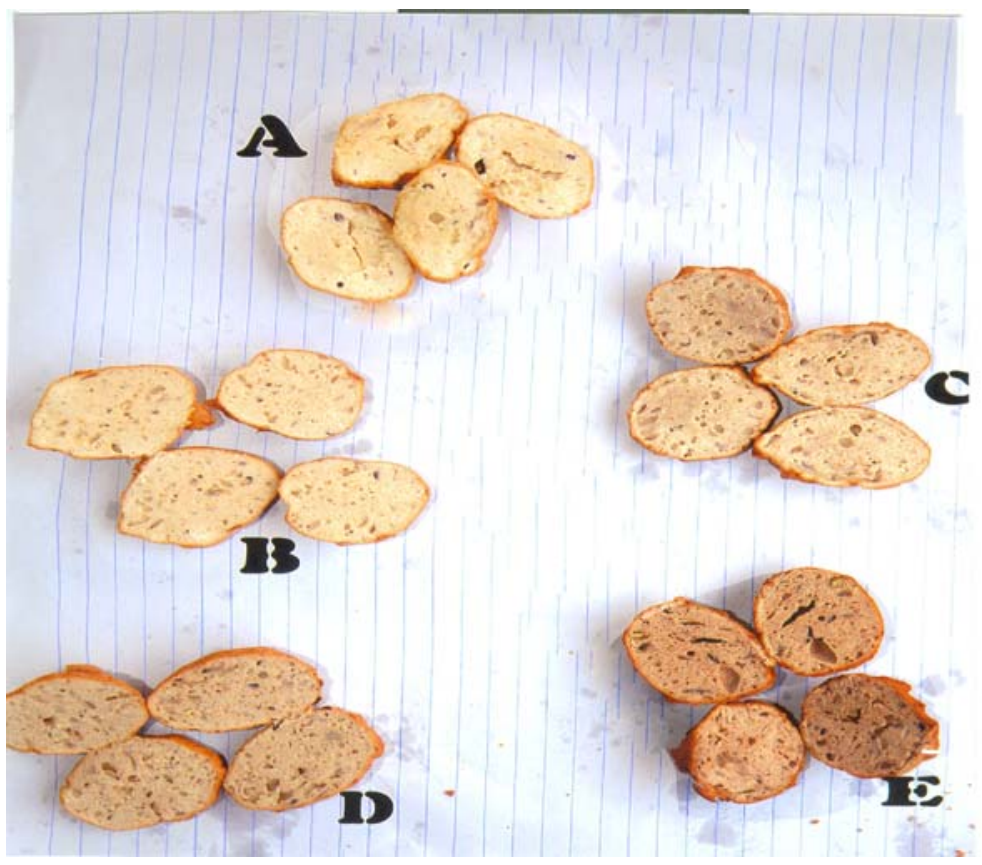

Figure 2. Akara halves from bambara groundnut flour containing $G$. venusta $(\%, w / w)$ showing crumbs. $A=0, B=0.5, C=1.0, D=1.5, E=2.0$.

mucilage is shown in Table 3. The moisture content of the akara with no mucilage (control) was significantly lower than those containing mucilage. Akara with $2.0 \%$ mucilage had the highest moisture content, which was however not significantly different $(p \geq 0.05)$ from those containing $1.0 \%$ and $1.5 \%$ mucilage. This suggests that the mucilage improved moisture retention in the akara. The fat and ash contents of the akara increased while the 
carbohydrate decreasedwith increasing mucilage addition. The increase in the fat content among akara containing mucilage was probably due to absorption of oil during frying. The increases were however not significant. The increasing number of air spaces, which resulted in the spongy crumb of the akara also increased oil penetration. The protein content of the akara samples decreased with increasing level of mucilage. This trend may be due to a dilution effect of the mucilage. The fibre content of the akara increased with increasing level of mucilage addition. Mucilage is made up of complex polysaccharides otherwise known as mucopolysaccharides, which constitute fibre that is non digestible. Dietary fibre belongs to the class of ingredients classified as functional foods (Gernah and Tersoo-abiem, 2010). These are products derived from naturally occurring substances consumed as part of the daily diet that offer particular physiological benefits other than purely nutritional benefits when ingested (Onuorahet al., 2004). High fibre content of theakaras would contribute to increase in their bulk and reduce bowel transit time when the foods are ingested. A reduced bowel transit time would prevent putrefaction of proteins, oxidation and rancidity of fats as well as fermentation of carbohydrates to produce gas that creates flatulence as well as toxins in the bowel. In most instances, the toxins could cause problems such as neck and shoulder pain, waist and skin problems, fatigue, sluggishness and neurological problems (Arogba, 2008).

The akara with $0 \%$ and $0.5 \%$ mucilage had the most attractive colour as shown by the panelists' scores. The colour of akara with $1.0 \%$ and $1.5 \%$ mucilage was not different significantly.The akara became more brownish as percentage mucilage increased. The sample with $2.0 \%$ mucilage, which had the lowest score for colour was scored highest for taste, texture, flavour and overall acceptability. It appeared that colour may not be a major factor that would discourage consumers from accepting BGN akara.

\section{CONCLUSION}

G. venusta mucilage appeared to affect the physical, chemical and organoleptic properties of akara prepared from bambara groundnuts. The results suggest that apart from protein and colour, the quality of bambara groundnut akara improved upon addition of the mucilage. The use of bambara groundnuts to prepare akara containing $G$. venusta mucilage could lead to the diversification of the nuts as well as application of a lesser knowm mucilage. We are carrying out the toxicological effects of the mucilage on rats in our laboratory.

\section{REFERENCES}

Akinjayeju O,Enude OT (2002). Effect of dehulling on some properties of cow pea (VignaunguiculataWalp L.) flours. Italian J. Food Sci. 14(1): 53-58.

Alobo AP (1999). Production and organoleptic assessment of akara from bambara groundnut (Voandzeiasubterranae (L.) Thouars). Plant Foods Hum. Nutr. 53: 313-320.

Anonymous (2010). Gums and mucilages. http://www.herbs2000.com Accessed 15/1/2013.

AOAC (2005). Official Methods of Analysis. $18^{\text {th }}$ edition. Association of Official Analytical Chemists. Washington D.C USA.

Arogba SS (2008). Phenolics: A class of nature's chemical weapons of self-preservation. First Inaugural Lecture. Department of Biochemistry, Kogi State University, Anyigba.

Asiedu JJ (1989). Processing Tropical Crops: A Technical Approach. Macmillan Publishers Ltd, London.

ChineduSN Nwinyi CO (2012). Proximate analysis of Sphenostylisstenocarpa and Voandzeia subterranean consumed in South-Eastern Nigeria. J. Agric. Ext. Rural Dev. 4(3): 57-62. http://academicjournals.org/aerd Accessed on 02/10/2014.

Dawidowsky $F(2009)$. Glue, Gelatin, Animal Charcoal, Phosphorus, Cement, Pastes and Mucilage. Bibilife. ISBN 978-1-113-00611-0. http://en-m.wikipedia.org/wi. Accessed on 02/10/2014.

Gernah DI,Tersoo-abiem EM (2010). Functional foods, nutriceuticals and health. Nigerian Food J. 28(2): 121-131.

Ihekoronye Al, Ngoddy PO (1985). Integrated Food Science and Technology for the Tropics. Macmillian Publishers, London,

Lete (2013). Nigerian Akara Recipe: How to make akara. http//:www.nigerianfoodtv.com/2013/02/how-to-make-akara.com Accessed on 09/10/2014.

Mazahib AM, Nuha MO, Salawa IS, Babiker EE (2013). Some nutritional attributes of bambara groundnut as influenced by domestic processesInt. Food Res. J. 20(3): 1165-1171.

Ngoddy PO, Enwere NJ,Onuorah VT (1986). Cow pea flour performance in 'akara' and 'moin-moin' preparation. Tropical Science. 26: 101-109.

Olapade A, Adetuyi DO (2007). Comparison of different methods of producing bamara (Voandzeiasubterraneae(L.) Thou) flours for preparation of'moin-moin. Nigerian Food J. 25(2): 150-157.

Olusola A, Abayomi TG, Olutayo O (2014). Carboxymethylation of Anacardiumoccidentale $\mathrm{L}$. exudate gum: Synthesis and characterization. Scholars Academic J. Pharm. 3(2): 213-216.

Onuorah CE, Ayo JA, Uhiara NS, Jideani VA (2004). Food Product Development. Amana Printing and Advertising Ltd, Kaduna, Nigeria. Pp 78-82.

Rachie KO, Sylvester P (1977). Grain legumes. In: Leakey, C. L. A. and Wills, J. B. (Eds). Food Crops of the Low Land Tropics. Oxford University Press, London. Pp41-74.

How to cite this article: Alobo, Arubi P and Arueya, Gibson L. (2014). Effect of Grewia venusta('Ururu') mucilage on the physicochemical and sensory properties of fried cake ('akara') prepared from bambara groundnut seed flour. Afr. J. Food Sci. Technol. 6(1):12-17 